ZOOLOGIA 29 (5): 479-482, October, 2012

doi: $10.1590 /$ S1984-46702012000500013

\title{
A new species of Tipuana (Auchenorrhyncha: Cicadellidae: Cicadellini) from the state of Amazonas, Brazil, with a key to males of the genus
}

\author{
Rodney Ramiro Cavichioli ${ }^{1} \&$ Gabriel Mejdalani²
}

\author{
${ }^{1}$ Departamento de Zoologia, Universidade Federal do Paraná. Caixa Postal 19020, 81531-980 Curitiba, PR, Brazil. \\ E-mail: cavich@ufpr.br \\ 2 Departamento de Entomologia, Museu Nacional, Universidade Federal do Rio de Janeiro. Quinta da Boa Vista, \\ São Cristóvão, 20940-040 Rio de Janeiro, RJ, Brazil. E-mail: mejdalan@acd.ufrj.br
}

\begin{abstract}
A new species of Tipuana Melichar, 1926, T. similis sp. nov., is described and illustrated based on specimens from the state of Amazonas, northern Brazil. The new taxon is externally very similar to T. chirensis Young, 1977. It can be distinguished from the latter and from the other known species of the genus mainly by the aedeagus with a triangular, posteriorly directed projection between the basidorsal apodemes, and with shaft not expanded apically and bearing two sharp, short apical processes curved dorsally. Diagnostic features of the new species are also found in the paraphysis, which is symmetrical, expanded towards the apex and with a round apical excavation. A key to the species of Tipuana (males) is added.
\end{abstract}

KEY WORDS. Cicadellinae; Membracoidea; morphology; sharpshooter; taxonomy.

Tipuana was established by Melichar (1926: 344) in a taxonomic key, and Evans (1947: 164) designated Tipuana egregia (nomen nudum) as the type-species of the genus. Metcalf (1965) listed the genus as an invalid taxon in his catalog. Young (1977) redescribed Tipuana, recognized Melichar as the author of the genus, and included three species: T. albula (Osborn, 1926), T. chirensis Young, 1977, and T. expallida Young, 1977, the latter designated as the type-species. Young (1977) noted that $T$. expallida was the same species as Melichar's unpublished interpretation of T. egregia. Young (1977) diagnosed the genus as follows: (1) head, in dorsal view, moderately to well produced anteriorly; (2) ocelli located posteriorly to the imaginary line between the anterior angles of the eyes; (3) epistomal suture incomplete; (4) pronotum wider than the transocular width, its lateral margins (5) converging anteriorly and the disk (6) without transverse rugae; (7) forewings without membrane, the veins (8) usually indistinct at base of anteapical cells and (9) with four apical cells. Tipuana was included in the Diedrocephala generic group sensu Young (1977: 325) along with 13 other genera. According to Young (1977), it is morphologically similar to Diedrocephala Spinola. It differs from the latter in having four apical cells in the forewings and the apex of the outer anteapical cell reaches the base of the apical cells. Tipuana is also related to Platygonia Melichar. However, species of the latter genus have a carina at the transition between the crown and the face. Tipuana is recorded from French Guiana, Brazil, Ecuador and Peru (Young 1977).

Based on specimens collected in Ipixuna, state of Amazonas, northern Brazil, a new species of Tipuana, T. similis sp. nov., is herein described and illustrated. A key to male speci- mens of the genus is provided, which is modified from that of Young (1977: 335).

\section{MATERIAL AND METHODS}

The specimens studied are deposited in the following Brazilian institutions: Instituto Nacional de Pesquisas da Amazônia, Manaus (INPA) and Coleção Entomológica Pe. Jesus Santiago Moure, Departamento de Zoologia, Universidade Federal do Paraná, Curitiba (DZUP). The terminology follows mainly Young $(1968,1977)$, except for the head morphology (Hamilton 1981, Mejdalani 1998) and the leg chaetotaxy (Rakitov 1997). The male genitalia were prepared according to OMAN (1949) with the following modifications: the parts were soaked in boiling potassium hydroxide, transferred to lactic acid for five minutes and then to $50 \%$ ethanol for two minutes to remove air bubbles. The structures were examined, photographed and illustrated on concave slides with glycerin. They were stored in microvials with glycerin. In the quotations of collecting data, a backslash $(\backslash)$ indicates line breaks on the label.

\section{TAXONOMY}

Tipuana similis Cavichioli \& Mejdalani, sp. nov. Figs $1-7$

Diagnosis. General coloration dark brown, wings translucid; venation indistinct (Fig. 1). Aedeagus (Figs 6 and 7) symmetrical, with triangular, posteriorly directed projection between basidorsal apodemes; shaft short, not expanded apically, and with two sharp, short apical processes curved 


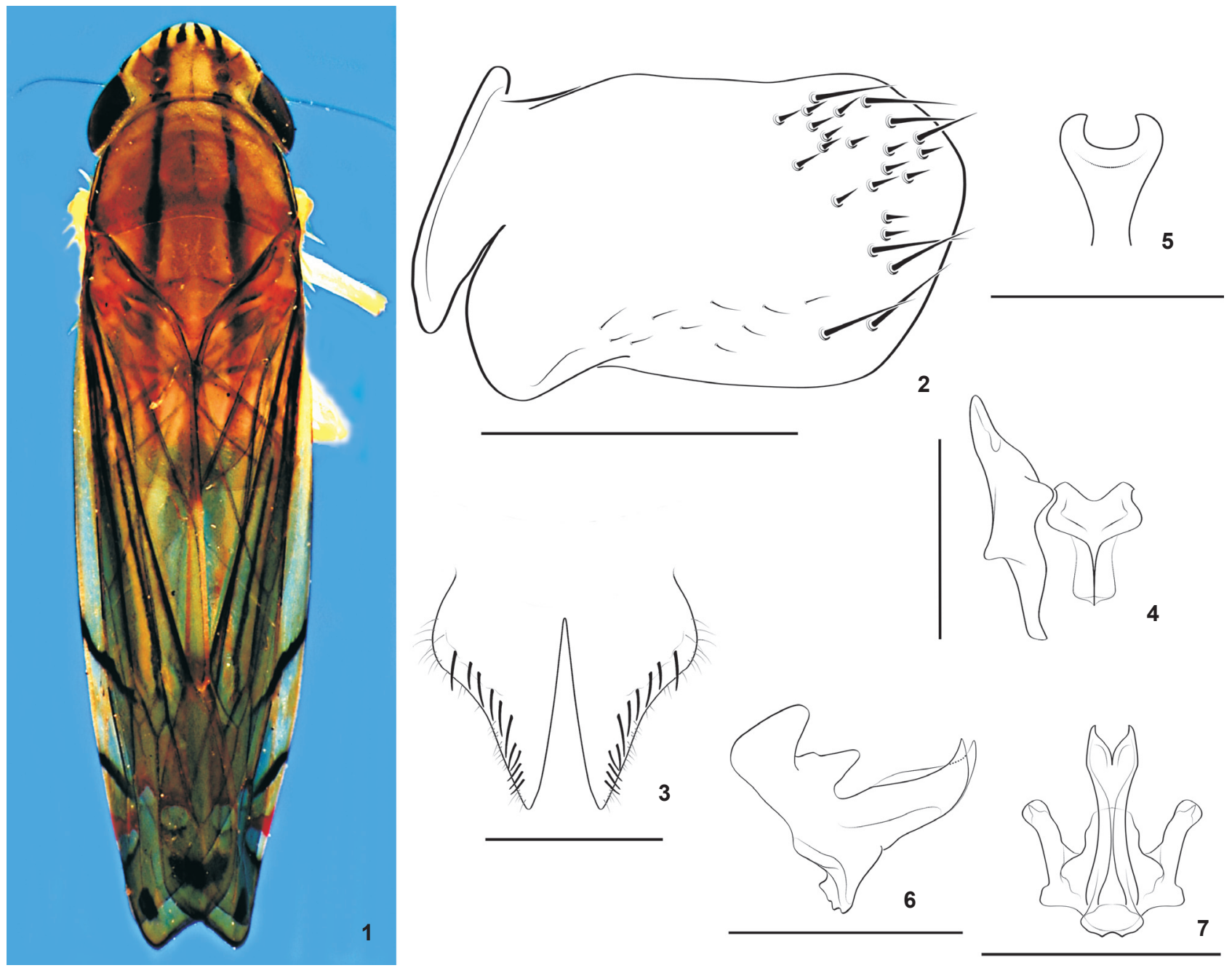

Figures 1-7. Tipuana similis sp. nov., male: (1) body, dorsal view, length $8 \mathrm{~mm}$; (2) pygofer, lateral view; (3) subgenital plates, ventral view; (4) connective and style, dorsal view; (5) paraphysis, posterior view; (6) aedeagus, lateral view; (7) aedeagus, caudal view. Scale bars $=0.5 \mathrm{~mm}$.

dorsally. Paraphysis (Fig. 5) symmetrical, expanded towards apex, with round apical excavation.

Description. Holotype male.

Length. Male holotype and paratype, $8 \mathrm{~mm}$.

Head and thorax. Crown (Fig. 1), in dorsal view, well produced anteriorly; anterior margin broadly rounded; median length approximately $7 / 10$ of interocular width, slightly smaller than $1 / 2$ transocular width; ocelli located slightly behind imaginary line between anterior angles of eyes; crown with pair of foveae between eyes and ocelli; antennal ledges, in dorsal view, weakly pronounced, oblique and slightly carinate in lateral view. Face with frons flat medially; muscle impressions indistinct. Hindtibiae with anterodorsal row formed by large macrosetae and short intercalary setae (usually two in between macrosetae). Forewings (Fig. 1) with veins mostly indistinct, except apically; anteapical cells poorly delimited. Other generic characters as in Young (1977: 334).

Coloration. Head, pronotum and mesonotum yellowishbrown; forewings translucent (Fig. 1). Head, in dorsal view, with four black short longitudinal stripes on median anterior portion; two other small black stripes on antennal ledges; two long dark brown bands, slightly divergent, extending from the two outermost stripes on anterior margin of head to about middle of clavus; frons and clypeus pale yellow. Pronotum with two longitudinal black lines on lateral margins, next to each side of dorsopleural carina; remainder of thorax and legs mostly pale yellow. Forewings translucent amber; costal margin with triangular hyaline area extending from base to apical portion; 
two longitudinal dark brown stripes close to claval suture, with yellow stripe between them; oblique dark brown band extended from costal margin to stripes close to claval suture; triangular hyaline area at costal apical third, delimited by dark lines, with transverse red stripe at middle; two orange maculae next to two hyaline spots at apical portions of innermost anteapical cells; two small circular dark brown to black spots on first and third apical cells.

Male genitalia. Pygofer (Fig. 2), in lateral view, moderately produced posteriorly, more or less rectangular, basiventral margin with distinct lobe, posterior margin broadly round and slightly obtuse at upper third; macrosetae distributed mostly on apical third. Valve broad, transverse, with posterior margin emarginated. Subgenital plates (Fig. 3), small; in ventral view, weakly fused to each other basally, triangular, wider at basal third, gradually narrowed towards apex; with uniseriate macrosetae and several microsetae along outer margin; in lateral view, not extending as far posteriorly as pygofer apex. Styles (Fig. 4), in dorsal view, with prominent median lobe, apex truncated. Connective (Fig. 4), in dorsal view, Y-shaped, with arms short and robust, stalk with distinct median keel, extended to apical third of styles. Aedeagus (Figs 6 and 7) symmetrical, with triangular projection between basidorsal apodemes in lateral view, directed posteriorly; shaft of aedeagus short, not expanded apically, with two sharp, short apical processes curved dorsally; ventrobasal process short, truncated, margins serrated. Paraphysis (Fig. 5) symmetrical, expanded towards apex, with conspicuous, round apical excavation.

Female unknown.

Taxonomic summary. Holotype male, BraziL, Amazonas: "Ipixuna - Am[azonas]; Rio \Liberdade; Com. [Comunidade] São \Vicente (Estirão da \Preta) $7^{\circ} 21^{\prime} 47^{\prime \prime S} \backslash 71^{\circ} 52^{\prime} 7^{\prime \prime} \mathrm{W}^{\prime}$, " 175 m Light trap \11-14/V/2011 \Cavichioli, Gonçalves \& Takiya" (INPA). Paratype male [abdomem missing]: "Ipixuna - Am; Rio \ Liberdade; Com. [Comunidade] Sta [Santa] \Catarina 7¹9'46"S \7151'46"W 170 m;", "light trap \10/V/2011 Cavichioli, \Gonçalves \& Takiya" (DZUP).

Etymology. The species epithet refers to the similarity in coloration with T. chirensis Young, 1977.

Comments. Tipuana similis sp. nov. closely resembles $T$. chirensis Young, 1977 in the general coloration (Fig. 1). The color of the head and thorax is also similar to T. expallida Young, 1977 [the forewings of the specimen studied by Young (1977) are missing]. The new species can be distinguished from other species in the genus by the shape of styles (Fig. 4), connective (Fig. 4), aedeagus (Figs 6 and 7) and paraphysis (Fig. 5). The latter is symmetrical in the new taxon, in contrast with other valid species of Tipuana. In the description of the genus, Young (1977) specified that paraphysis or paraphyses were present, symmetrical or not. However, all species he recognized have asymmetric paraphyses or paraphysis. Specimens with symmetrical paraphyses or paraphysis were illustrated but not formally described (YounG 1977: 337-338, figs 273-274, both referred to as 'Tipuana sp.').
Tipuana similis sp. nov. was collected in the municipality of Ipixuna, state of Amazonas, in a "terra-firme" forest, in two communities along the Liberdade river, close to the borders of the state of Acre and Peru. This species can be appended to the couplet 2 of Young's (1977: 335) key, as proposed below.

\section{Species of Tipuana}

T. albula (Osborn), 1926. French Guiana, Brazil.

T. chirensis Young, 1977. Peru.

T. expallida Young, 1977. Peru.

T. similis sp. nov. northern Brazil (Amazonas).

\section{Key to males of Tipuana (modified from Younc 1977)}

1. Forewings opaque; aedeagus with a median ventral keel in basal half ..... T. albula (Osborn)

1 '. Forewings pale translucent; aedeagus not keeled ............. 2

2. Paraphyses asymmetrical 3

2 '. Paraphysis symmetrical T. similis sp. nov.

3. Styles truncate apically; aedeagus without apicoventral processes; pygofer with dorsoapical margin not truncate T. chirensis Young

3 '. Styles narrowly rounded apically; aedeagus with apicoventral processes; pygofer produced and truncate dorsoapically.. .. T. expallida Young

\section{ACKNOWLEDGMENTS}

A preliminary version of this manuscript benefited from comments and corrections by Olivia Evangelista (Departamento de Zoologia, UFPR) and two anonymous reviewers. The authors are research productivity fellows from the Conselho Nacional de Desenvolvimento Científico e Tecnológico (CNPq, processes 303.127/2010-4 and 301.391/2011-4, respectively). This research was partially funded by PROTAX/CNPq research grants (process 561.298/2010-6). This paper is the contribution number 1877 of the Departamento de Zoologia, Universidade Federal do Paraná. Specimens were collected with the aid of the project "Amazonas: diversidade de insetos ao longo de suas fronteiras", headed by José A. Rafael (INPA, PRONEX, FAPEAM, process 1437/2007/NTO318/07).

\section{LITERATURE CITED}

Evans, J.W. 1947. A natural classification of leaf-hoppers (Jassoidea, Homoptera). Part 3: Jassidae. Transactions of the Royal Entomological Society of London 98: 105-271.

HamiLton, K.G.A. 1981. Morphology and evolution of the rhynchotan head (Insecta: Hemiptera, Homoptera). Canadian Entomologist 113: 953-974.

Mejdalani, G. 1998. Morfologia externa dos Cicadellinae (Homoptera, Cicadellidae): comparação entre Versigonalia ruficauda (Walker) (Cicadellini) e Tretogonia cribrata Melichar 
(Proconiini), com notas sobre outras espécies e análise da terminologia. Revista Brasileira de Zoologia 15: 451-544.

Melichar, L. 1926. Monographie der Cicadellinen. III. Annales Historico-Naturales Musei Nationalis Hungarici 23: 273394.

Metcalf, Z.P. 1965. General catalogue of the Homoptera. Fascicle VI, Cicadelloidea. Part 1, Tettigellidae. Washington, D.C., Agricultural Research Service, United States Department of Agriculture, 730p.

Oman, P.W. 1949. The Nearctic leafhoppers (Homoptera: Cicadellidae). A generic classification and check list. Memoirs of the Entomological Society of Washington 3: 1-253.

RaKiTOV, R.A. 1997. On differentiation of cicadellid leg chaetotaxy (Homoptera: Auchenorrhyncha: Membracoidea). Russian Entomological Journal 6: 7-27.

Young, D.A. 1968. Taxonomic study of the Cicadellinae (Homoptera: Cicadellidae), Part 1, Proconiini. Bulletin of the United States National Museum 261: 1-287.

Young, D.A. 1977. Taxonomic study of the Cicadellinae (Homoptera: Cicadellidae), Part 2, New World Cicadellini and the genus Cicadella. Technical Bulletin of the North Carolina Agricultural Experiment Station 239: 1-1135.

Submitted: 12.VI.2012; Accepted: 21.VII.2012.

Editorial responsibility: Walter A.P. Boeger 